\title{
Yaşlılarda Hipertansiyon
}

\author{
Hypertension In The Elderly
}

Merve KOLCU, Ayşe ERGÜN

ÖZ

Yaşlıda hipertansiyon, 65 yaşın üzerinde, sistolik kan basıncının 140mmHg'nın ya da diastolik kan basncının 90 mmHg'nın üzerinde olması ile tanımlanır. Hipertansiyon 65 yaş ve üzeri kişilerin yarısından fazlasında ciddi bir sağlık sorunudur. Yaşın ilerlemesiyle birlikte kan basıncı düzeyi de artmaktadır. Türk Hipertansiyon Prevalans çalışmasına göre, hipertansiyon prevalansı 60-69 yaş grubunda $\% 70,70-79$ yaş grubunda $\% 76,80$ yaş ve üstünde ise \%79.7'ye ulaşmaktadır. Hipertansiyonda erken tanı ve tedavi ile komplikasyonlar kolaylıkla önlenebilmektedir. Hipertansiyon tanısı anamnez, fizik muayene, tekrarlanan kan basıncı ölçümleri ve laboratuvar incelemeleri ile konur. Hipertansiyon tedavisi yaşam biçimi değişikliklerini kapsayan nonfarmakolojik tedavi ile ilaç tedavisini kapsayan farmakolojik tedaviden oluşmaktadır. Yaşın ilerlemesiyle birlikte, fiziksel ve bilişsel yetenekte azalma, kendi evinde yalnız kalma veya huzurevinde yaşama gibi nedenler tedaviye uyumu etkileyebilmektedir. $\mathrm{Bu}$ nedenlerle her hipertansif yaşlı birey sağlık personeli tarafından sık aralıklarla değerlendirilmeli, hipertansiyonun takip ve tedavisinde destekleyici yaklaşım sağlanmalıdır.

Anahtar kelimeler: Yaşlıda hipertansiyon, hipertansiyon, yaşlılar

Öğr. Gör. Dr. Merve KOLCU (伲)

Sağllk Bilimleri Üniversitesi Hemşirelik Fakültesi,Mekteb-i Tlbbiye-i Şahane, Selimiye Mah. Trbbiye Cad. No:38 34668 Üsküdar, İstanbul e-mail:merve.kolcu@sbu.edu.tr

Ayşe ERGÜN

Marmara Üniversitesi Sağllk Bilimleri Fakültesi, Hemşirelik Bölümü, Halk Sağlı̆̆l Hemşireliği Anabilim Dalı

\begin{abstract}
Hypertension in an elderly person is defined as having systolic blood pressure over $140 \mathrm{mmHg}$ or diastolic blood pressure over $90 \mathrm{mmHg}$ and being at the age of 65 and above. Hypertension is a serious health problem in over half of elderly people aged 65 and older. Blood pressure level also increases with increasing age. According to the Turkish Hypertension Prevalence Study, hypertension prevalence rises to $70 \%$ in the $60-69$ year-old age group, to $76 \%$ in the $70-79$ year-old age group and to $79.7 \%$ in people who are aged 80 and older. Early diagnosis and treatment can easily prevent complications with hypertension. Diagnosis of hypertension is established by anamnesis, physical examination, repeated blood pressure measurements and laboratory evaluations. Hypertension treatment is comprised of non-pharmacological treatments such as lifestyle changes, and pharmacological treatments, including pharmacotherapy. Reasons such as living alone at home or in nursing homes and reduced physical and cognitive abilities with increasing age can affect patients' compliance with treatment. Thus, each elderly hypertensive person should be frequently evaluated by health care personnel, and a supportive approach to the follow-up and treatment of hypertension should be adopted.
\end{abstract}

Keywords: Hypertension in the elderly, hypertension, the elderly

\section{Giriş}

Dünyadaki erişkin ölümlerin \%6'sı hipertansiyon kaynaklı olup, Dünya'da önlenebilir ölüm nedenleri içerisinde önde gelen risk faktörlerindendir $(2,19)$. Türkiye' de yaklaşık 1516 milyon hipertansiyon hastasının olduğu öngörülmektedir (14). Hipertansiyon 65 yaş ve üzeri kişilerin yarısından fazlasında ciddi bir sağlı sorunudur (27). Türk Hipertansiyon Prevalans çalışmasına (PatenT2) (2012) göre hipertansiyon prevalansı 18-29 yaş grubunda \%5 iken, 6069 yaş grubunda bu oran \%67.9'a kadar yükselmektedir (35). 
Yaşlılarda sık görülen bir sorun olan hipertansiyon, kontrol altına alınmadığında birçok sağlık sorununa neden olmaktadır. İnme, miyokard enfarktüsü, kalp yetmezliği, periferik vasküler hastalık ve kronik böbrek yetmezliği gibi hipertansiyon komplikasyonları yaşlılara daha fazla zarar vermektedir (25). Yaşlılarda hipertansiyonun tanı ve tedavisi son derece önemlidir. Hipertansiyon tedavisi yaşam biçimi değişikliklerini kapsayan nonfarmakolojik tedavi ile ilaç tedavisini kapsayan farmakolojik tedaviden oluşmaktadır.

$\mathrm{Bu}$ makalenin amacı, yaşlılarda hipertansiyon epidemiyolojisi, risk faktörleri ve tedavisini güncel bilgiler ile özetlemektir.

\section{Hipertansiyon Epidemiyolojisi}

Avrupa Hipertansiyon Derneği (ESH) ve Avrupa Kardiyoloji Derneği (ESC) 2013 Hipertansiyon Kılavuzu'na göre, Dünya'da genel popülasyonda hipertansiyon prevalans1 \%30-45 arasinda olup, 2025 yılında \%60'lara ulaşacağ 1 tahmin edilmektedir (40). Türkiye'de ise yaklaşık 15-16 milyon hipertansiyon hastasının olduğu öngörülmektedir (14). Hipertansiyon prevalansı ulusal çapta yapılmış dört büyük çalışmaya göre; Türk Erişkinlerinde Kalp Hastalıkları ve Risk Faktörleri (TEKHARF) (2004) çalışmasına göre \%33.7, Metabolik Sendrom Sıklı̆g 1 (METSAR) (2007) çalışmasına göre \%41.7, Diyabet, Hipertansiyon, Obezite ve Endokrinolojik Hastaliklar Prevalans (TURDEP 2) (2010) çalışmasına göre \%30, PatenT2 (2012) çalışmasına göre \%30.3 olarak bulunmuştur. Ulusal Hastalık YüküMaliyet Etkililik (2004) çalışmasına göre hipertansif kalp hastalığı bütün ölümlerin \%3'ünü oluşturmakta ve ulusal düzeyde ölüme neden olan hastalıklar içerisinde 6 . sırada yer almaktadır $(21,24,32,35,36)$.

Hipertansiyon 65 yaş ve üzeri kişilerin yarısından fazlasında ciddi bir sağlık sorunudur. Yaşın ilerlemesiyle birlikte kan basıncı düzeyi de artmaktadır. Türk Hipertansiyon Prevalans çalışmasına göre, 65 yaş ve üstünde hipertansiyon prevalansı erkekler için \%67.2, kadınlar için ise $\% 81.7$ 'dir. Hipertansiyon prevalans1 $60-69$ yaş grubunda $\% 70,70-79$ yaş grubunda $\% 76,80$ yaş ve üstünde ise \%79.7'ye ulaşmaktadır. İzole sistolik hipertansiyonun tüm yaş gruplarındaki prevalansı \%4.8iken, bu değer 60-69 yaş grubunda $\% 12$ 'ye, $70-79$ yaș grubunda $\% 17$ 'ye ve 80 yas ve üstü grupta ise \%28.6'ya ulaşmaktadır (35).

\section{Hipertansiyon Tanımı ve Risk Faktörleri}

Dünya Sağlık Örgütü (DSÖ) ve Uluslararası Hipertansiyon Komitesi (International Society of Hypertension-ISH) tarafından yapılan tanıma göre; hipertansiyon antihipertansif ilaç kullanmayanlarda sistolik kan basıncının $140 \mathrm{mmHg}$ veya üzerinde ve diastolik kan basıncının $90 \mathrm{mmHg}$ veya üzerinde olmasıdır. Hipertansiyon tanı ölçütleri yaşa göre değişim göstermediğinden, bu tanımlama yaşlılarda hipertansiyon tanımıyla aynidır $(20,37,40)$.

Altmış beş yaş üstündeki hipertansiyon vakalarının üçte ikisini izole sistolik hipertansiyon oluşturur. Bu olgularda sistolik kan basıncı $\geq 140 \mathrm{mmHg}$, diastolik kan basınc ise $\leq 90 \mathrm{mmHg}$ 'dır. İzole sistolik hipertansiyonda; artmış sistolik basıncın yanı sıra nabız basıncı, nabız dalga hızı ve karotis dalga refleksiyonları da kalp ve damarlarla ilgili riskleri arttırır (30). Hipertansiyon arter içi kan basıncının artması ile karakterize genetik, edinsel etmenler ve metabolik bozuklukların birlikte rol oynadığı bir sendromdur. Erken tanı ile kontrol altına alınabilen, geç kalındığında iskemik kalp hastalıkları, serebrovasküler hastalıklar gibi ölümcül seyreden komplikasyonlara ya da organ engeline yol açan ciddi bir hastalıktır $(19,37,40)$. Uluslararası Hipertansiyon ve Amerika Hipertansiyon Dernekleri tarafindan hazırlanan hipertansiyon yönetimi uygulama rehberlerine göre; kan basıncı düzeyleri ile kardiyovasküler hastalıklar, renal hastalıklar ve inme arasında anlamlı bir ilişki vardır. Kan basıncı ortalama değeri 115/75 mmHg olup, bu değerin üstünde sistolik basınç için her $20 \mathrm{mmHg}$, diastolik basınç için her 10 mmHg'lık bir artış kardiyovasküler hastalık ve inme riskini iki kat artırmaktadır (39). Bu nedenlerle hipertansif bireyin değerlendirilmesinde kardiyovasküler ve renal risk faktörlerinin tam olarak sorgulanması son derece hayatidir (4).

Avrupa Hipertansiyon Derneği ve Avrupa Kardiyoloji Derneği'nin Arteriyel Hipertansiyon Tedavisi 2013 Kılavuzu'na göre; hipertansiyonun değiştirilemeyen risk faktörleri arasında aile hikayesi, yaş, cinsiyet ve etnik yapı yer alırken, değiștirilebilen risk faktörleri arasında stres, obezite, beslenme ve madde kullanımı yer almaktadır (Tablo 1) (19). 
Tablo 1. Hipertansiyon Risk Faktörleri ${ }^{19}$

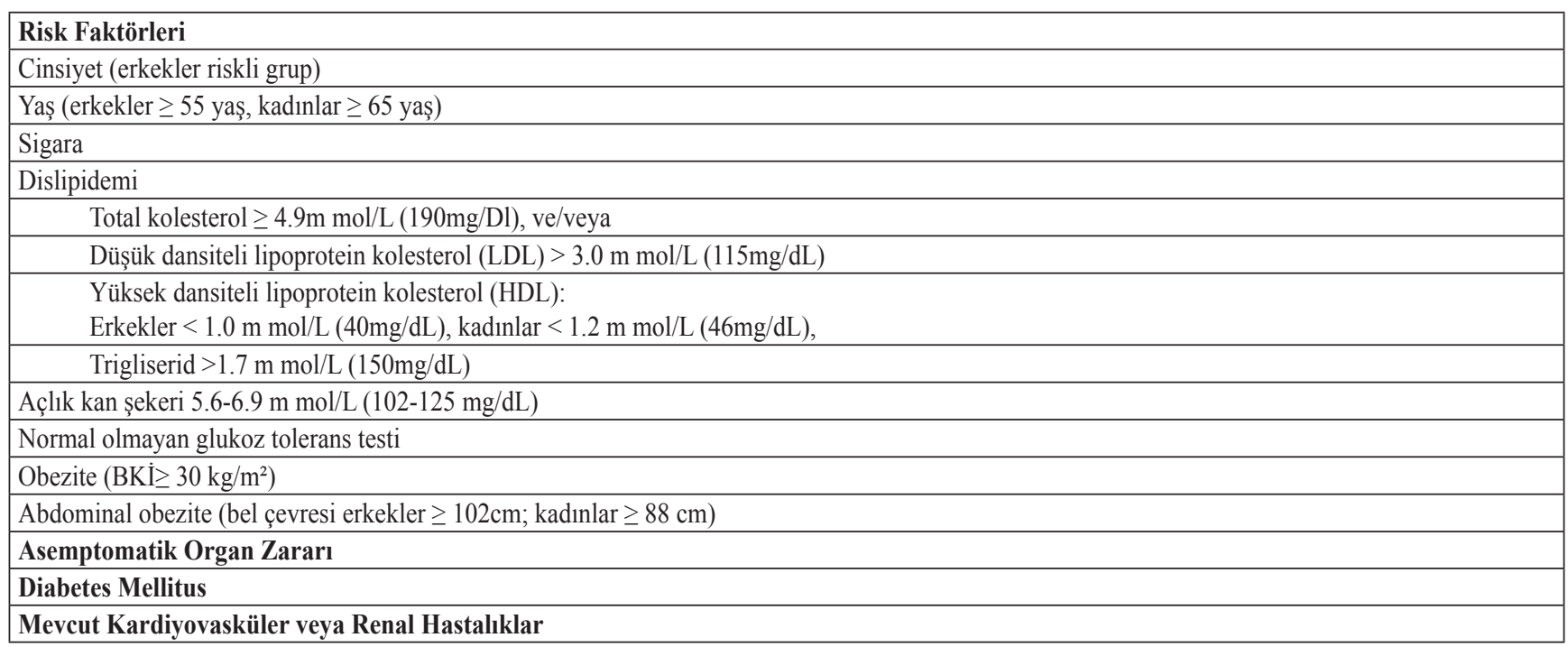

\section{Hipertansiyon Sınıflaması}

Hipertansiyonun sinıflaması genellikle kan basıncı değerlerine veya etiyolojik faktörlere göre yapılır. Pratikte tanı ve tedavi yaklaşımlarını basitleştirmek amacıyla hipertansiyon tıbbi tedavi öncesinde sistolik ve diastolik kan basıncı düzeylerine göre sınıflanmış ve derecesine göre tedavi önerilmiştir $(19,40)$.

Literatürde en çok kabul gören sınıflamalardan birisi ESH ve ESC Arteriyel Hipertansiyon Tedavisi 2013 Kilavuzu'na göre yapılan sınıflama olup Tablo 2'de verilmiştir (19).

\section{Hipertansiyon Nedenleri}

Hipertansiyon nedenleri primer ve sekonder olmak üzere iki grupta incelenir (Tablo 3).
Primer (Esansiyel, İdiyopatik) Hipertansiyon: Belirlenebilen organik bir neden olmaksızın kan basıncının yükselmesi şeklinde tanımlanır ve nedeni kesin olarak ortaya konulamamıştır. Yaşam tarzı, obezite ve fazla miktarda tuz tüketimi gibi nedenlerin etkili olabileceği düşünülmektedir. Hastaların \%90-95'inden primer hipertansiyon sorumludur. Sıklıkla yaşlı bireylerde görülmektedir $(4,13,19)$.

Sekonder Hipertansiyon: Arter basincındaki yükselmenin bir hastalığın çeşitli bulgularından birini oluşturduğu durumlardır. Sekonder nedenler daha çok genç yaş grubunda görülür ve hastaların yaklaşık \%5-10'unuoluşturur. En sık karşılaşılan renal nedenli sekonder hipertansiyondur ve hastaların \%2-5'inden sorumludur; bunu endokrin nedenler, uyku-apne sendromu, nörolojik nedenler ve aorta koarktasyonu izlemektedir (13, 19).

Tablo 2. Arteriyel Hipertansiyon Tedavisi Kılavuzu 2013'e göre Hipertansiyonun Sınıflaması ${ }^{19}$

\begin{tabular}{|l|l|l|l|}
\hline Kategori & Sistolik & & Diastolik \\
\hline İdeal & $<120$ & ve & $<80$ \\
\hline Normal & $120-129$ & $\mathrm{ve} / \mathrm{veya}$ & $80-84$ \\
\hline Yüksek normal & $130-139$ & $\mathrm{ve} / \mathrm{veya}$ & $85-89$ \\
\hline Evre 1 hipertansiyon & $140-159$ & $\mathrm{ve} / \mathrm{veya}$ & $90-99$ \\
\hline Evre 2 hipertansiyon & $160-179$ & $\mathrm{ve} / \mathrm{veya}$ & $100-109$ \\
\hline Evre 3 hipertansiyon & $\geq 180$ & $\mathrm{ve} / \mathrm{veya}$ & $\geq 110$ \\
\hline İzole sistolik hipertansiyon & $\geq 140$ & $\mathrm{ve}$ & $<90$ \\
\hline
\end{tabular}


Tablo 3. Hipertansiyonun Nedene Yönelik Sınıflaması ${ }^{13,19}$

\begin{tabular}{|c|c|}
\hline Primer (Esansiyel,İdiyopatik) Hipertansiyon & Sekonder Hipertansiyon \\
\hline $\begin{array}{l}\text { Nedenleri } \\
\text { *enetik yatkınlık } \\
\text { Aşırı tuz tüketimi } \\
\text { Obezite } \\
\text { Artmış sempatik aktivite } \\
\text { Renin anjiotensin sisteminin rolü } \\
\text { * Tuz atılımında renal bozukluk } \\
\text { Intraselüler sodyum ve kalsiyum artışı } \\
\text { Düşük doğum ağırlığı } \\
\text { * Aceleci, sabırsız, stresli kişilik yapısı } \\
\text { Arttıran Faktörler } \\
\text { * Aşırı alkol alımı, } \\
\text { * Sigara, } \\
\text { * Sedanter hayat, } \\
\text { Polisitemi, } \\
\text { * Nonsteroid antiinflamatuvarlarlar, }\end{array}$ & $\begin{array}{l}\text { Renal Nedenler } \\
\text { Rronik piyolonefrit } \\
\text { Akut ve kronik glomerülonefrit } \\
\text { Renikistik böbrek hastalığı } \\
\text { Arterioler darlığı } 1 \\
\text { Diyabetik nefrosklerozati } \\
\text { Renin salgılayan tümörler } \\
\text { Endokrin Nedenler } \\
\text { 1. Oral kontraseptifler } \\
\text { 2. Adrenokortikal Hiperfonksiyon } \\
\text { a. Cushing sendromu } \\
\text { b. Primer hiperaldosteronizm } \\
\text { c. } \text { Konjenital adrenal hiperplazi } \\
\text { 3. Feokromositoma } \\
\text { 4. Miksödem } \\
\text { 5. Akromegali } \\
\text { 6. Hipotiroidi, hipertiroidi } \\
\text { 7. Hiperparatiroidi } \\
\text { Uyku- apne sendromu } \\
\text { Nörolojik nedenler } \\
\text { Aorta koarktasyonu }\end{array}$ \\
\hline
\end{tabular}

\section{Hipertansiyon Tanısı}

Hipertansiyon tanısı anamnez, fizik muayene, tekrarlanan kan basıncı ölçümleri ve laboratuar incelemeleri ile konur $(13,22)$.

\section{Anamnez}

Anamnezde dikkat edilmesi gerekenler şunlardır (11, 13, 22):

- Kan basıncı yüksekliğinin süresi ve daha önceki düzeyleri

- Sekonder hipertansiyon nedenlerine yönelik semptomları ve kan basıncını arttırması olası ilaç ve madde kullanımı (oral kontraseptifler, meyan kökü, kokain, amfetaminler, steroidler, steroid olmayan antienflamatuar ilaçlar gibi)

- Hastanın koroner kalp hastalığı, kalp yetersizliği, serebrovasküler hastalık, periferik arter hastalığ 1 , Diabetes Mellitus, gut, dislipidemi, astım, böbrek hastalığı ve diğer önemli hastalıkları ile ilgili geçmişi, bu klinik tablolarla ilgili şimdiki semptomları ve bu tabloların tedavisi için kullanılan ilaçları ve sonuçları ile ilgili bilgileri,
- Hipertansiyon, diyabet, dislipidemi, kalp yetersizliği, serebrovasküler olay veya böbrek hastalığı ile ilgili aile anamnezi,

- Hastanın yaşam biçimi alışkanlıkları (sigara içiyorsa süresi ve miktarı, alkol kullanım miktarı, diyetteki yağ cinsi ve ilave tuz kullanımı, fizik aktivite düzeyi, erken erişkin yaşamda başlayan kilo alımı),

- Hipertansiyonun seyri ve sonuçlarına etki edebilecek kişisel psikososyal ve çevresel faktörler (örneğin çalışma ortamı, öğrenim durumu, sosyokültürel ve sosyoekonomik yapısı gibi) sorgulanmalıdır.

\section{Fizik Muayene}

Yaşlı bireyin fizik muayenesinde; kan basıncı ölçümü yapılmalı, boy ve kilo ölçümleri yapılarak vücut kitle indeksi hesaplanmalı, bel çevresi ölçülmeli, kalp yetmezliği belirtileri ile nörolojik değerlendirme yapılmalı, gözler ve periferik nabız kontrol edilmelidir $(18,23,33)$.

\section{Kan Basıncı Ölçümü̈}

Günümüzde en yaygın kullanılan kan basıncı ölçüm tekniği, civalı sfigmomanometre kullanımına dayalı Krotkoff tekniğgidir $(11,13)$. 
Kan basıncı ölçümünde dikkat edilmesi gerekenler şunlardır; ölçüm sırasındaki çevresel ve bireysel koşullar kan basıncını etkilemektedir. Ölçümün hangi saatlerde yapıldığı bilinmeli ve kayıt edilmelidir. Ölçüm öncesindeki 30 dakikalık süre içinde hastanın sigara, çay veya kahve içmemiş, kafein almamış ve tercihen yemek yememiş olması gerekir. Fenilefrinli nazal dekonjestanlar veya benzeri adrenerjik uyarıcıların kullanımı da sonucun yanlış çıkmasına neden olabilir. Ölçümlere, sessiz bir odada hasta en az 15 dakika istirahat ettikten sonra başlanmalıdır. Hasta sırtını yaslayarak oturmalı, tansiyon ölçülecek kol çıplak olmalıdır. Ölçüm sırasında konuşmamalı, bacak bacak üstüne atmamalıdır. Manşon kalp düzeyinde duracak şekilde sarılmalı ve kol desteklenmelidir $(11,13)$.

\section{Laboratuar İncelemeleri}

Yaşlı hipertansif kişilerde yapılacak laboratuar incelemeleri (kan ve idrar incelemeleri), risk düzeyinin saptanmasına, sekonder hipertansiyonun ve hedef organ hasarının olup olmadığının belirlenmesine yöneliktir (22).

Hipertansif kişilerde incelenmesi gereken kan değerleri; elektrolitler (özellikle potasyum ve diğer elektrolitler), glukoz konsantarayonu, serum kreatinin, lipidler (total kolesterol, LDL-kolesterol, HDL kolesterol, açlık serum trigliseridleri), hemoglobin/hemotokrit, karaciğer fonksiyon testleridir. Hipertansif kişilerde incelenmesi gereken idrar değerleri ise albumin, kreatinin, kırmızı ve beyaz kan hücreleridir $(8,10,22)$.

\section{Yaşlılarda Hipertansiyon Tedavisi}

Yaşlılarda hipertansiyon tedavisinin amaçları; kan basıncını 140/90 mmHg'nın altına düşürmek, hedef organ hasarını durdurmak veya geriletmek, aterosklerozu önlemek, yaşam kalitesini korumaktır (12).

Yaşlılarda antihipertansif tedavinin kardiyovasküler mortalite ve morbiditede anlamlı olarak azalma sağladığı bildirilmektedir. Kan basıncının kontrol altında olması, koroner arter hastalığını \%27 oranında azaltmaktadır. Erdine ve arkadaşlarının (2007) yaptığı çalışmaya göre; yüksek kan basıncının kontrol altına alınması gençlerde inmeyi \%28 oranında azaltırken, yaşlılarda bu oran \%36'dır (12, 26, 38). Yaşlılarda hipertansiyon tedavisi, nonfarmakolojik ve farmakolojik tedavi olarak ikiye ayrılmaktadır (29).

\section{Nonfarmakolojik Tedavi}

Nonfarmakolojik tedavi daha geniş bir isimlendirme ile yaşam biçimi değişiklikleri olarak adlandırılmaktadır. Sağlıklı yaşam biçimi davranışları ile kan basıncının düşürülmesi, diğer risk faktörleri ile klinik durumların kontrol altına alınması ve kullanma ihtimali olabilecek antihipertansif ilaç sayısının ve dozunun azaltılması amaçlanmaktadır (19).

Özellikle hafif hipertansiyonlu hastalarda farmakolojik tedaviden önce uygulanması ve tüm farmokolojik tedavi programlarının tamamlayıcısı olması önerilmektedir $(7,11$, 28). Yaşam biçimi değişiklikleri beden kitle indeksini normal sinırda tutmak, tuz tüketimini azaltmak, sebze ve meyveden zengin düşük yağlı veya yağdan fakir günlük ürünlerle ve azalmış satüre ve total yağ içeriği olan başka bir deyişle potasyum, magnezyum, kalsiyum, fiber ve proteinden zengin diyet uygulamas1 (DASH diyeti), haftada 4-7 kez 3060 dakika orta şiddette fiziksel egzersiz, sigarayı ve alkol tüketimini bırakmak ve stresle mücadeleyi kapsamaktadır $(1,3,5,31,34)$.

Hipertansif yaşlılarda mevcut fiziksel ve bilişsel durum nedeniyle yaşam biçimi değişikliklerinin uygulaması ve davranış değişikliğine dönüştürülmesi güç olabilir. $\mathrm{Bu}$ nedenle sağlı personeli tarafindan yaşlı bireylerin takip ve değerlendirilmesi son derece önemlidir $(5,34)$.

\section{Farmakolojik Tedavi}

Yapılan çalışmalar ilaçsız tedavi yöntemlerinin, hipertansiyonun kontrol altına alınması açısından tek başına yetersiz kalsalar bile kan basıncını düşürdüğünü, hastalığın kontrol edilmesi için gereken ilaç sayısını ve dozlarını azaltabileceğini göstermektedir. $\mathrm{Bu}$ nedenle tüm kılavuzlarda yaşam tarzı değişiklikleri tedavinin ilk basamağı olarak vurgulanmaktadır (9). Yaşam tarzı değişikliği ile hedef kan basıncı sağlanamazsa ilaç tedavisi gereklidir. Yaşı hastalarda ilaç seçiminde; genç hastalarda olduğu gibi hedef organ hasarı eşlik eden faktörler ve hastalıkları, ilaçların yan etkileri ve doz gibi konular göz önüne alınarak karar verilmelidir. Başlangıç dozu genç hastalarda kullanılan dozun yaklaşık yarsı kadar olmalı ve doz gerektikçe yavaş yavaş artırılmalı ve ilaç tedavisinin riskleri düşünülmelidir $(15,16)$.

Yaşlı hipertansiflerde verilen antihipertansif ilaçlar gençlerde olduğu gibi şu şekilde gruplandırılabilir $(15,16)$;

- Diüretikler 
- Beta blokerler

- Anjiyotensin dönüştürücü enzim (ACE) inhibitörleri

- Anjiyotensin II reseptör blokerleri (ARB)

- Kalsiyum kanal blokerleri

- Alfa blokerlerdir.

Yapılan çalışmalar ve tedavi rehberleri birlikte değerlendirildiğinde; eşlik eden başka hastalığı olmayanlarda tedaviye diüretiklerle başlayıp hedef kan basıncına ulaşılamazsa, beta blokerler veya anjiyotensin dönüştürücü enzim inhibitörleri tedaviye eklenmektedir. Yeni bir tedavi başlandıktan sonra ilk üç ay yaşlı hastanın daha yakından takip edilmesi, eğer sorun yoksa altı ayda bir kontrollere çağrılması uygundur $(6,17)$.

\section{Sonuç}

Yaşlılarda hipertansiyon diğer yaş gruplarından farklı özellikler taşır. Erken tanı ve tedavi ile komplikasyonlar kolaylıkla önlenebilmektedir. Ancak yaşın ilerlemesiyle birlikte yaşlılarda fiziksel ve bilișsel yetenekte azalma, kendi evinde yalnız kalma veya huzurevinde yaşama gibi nedenler tedaviye uyumu etkileyebilmektedir. $\mathrm{Bu}$ nedenle her hipertansif yaşlı birey sağlık personeli tarafından sık aralıklarla değerlendirilmeli, hipertansiyonun takip ve tedavisinde destekleyici yaklaşım sağlanmalıdır.

\section{KAYNAKLAR}

1. Appel LJ., Brands MW., Daniels SR., Karanja N., Elmer PJ., Sacks FM. Dietary approaches to prevent and treat hypertension. A scientific statement from the Heart Association, Hypertension, (2006), 47: 296-308.

2. Banegas JR., Guallar-Castillón P., Rodrı'guez-Artalejo F., Graciani A., López-Garc1'a E., Ruilope LM. Association between awareness, treatment, and control of hypertension, and quality of life among older adults in Spain. Am J Hypertens, (2006), 19: 686-693.

3. Barbosa AR., Munaretti DB., Coqueiro RS., Borgatto AF. Anthropometric indexes of obesity and hypertension in elderly from Cuba and Barbados. The Journal of Nutrition, Health \& Aging, (2011), 15(1): 17-21.

4. Bunker SJ., Colquhoun DM., Esler MD., Hickie IB., Hunt D., Jelinek VM., Oldenburg BF., Peach HG., Ruth D., Tennant CC., Tonkin AM. Stress and coronary heart disease psychosocial risk factors. Med J Aust, (2003), 178: 272-276.

5. Cappucio FP., Gomez GB. Yaşam Tarzı Değişiklikleri ve İlaçsız Tedavi. İçinde: Hipertansiyon Temelleri ve Uygulama. Ed: Kozan Ö., Avrupa Tıp Kitapçılık Ltd Şti., İstanbul, (2009), s: 383-403.
6. Chobanian AV., Bakris GL., Black HR., Cushman WC., Green LA., Izzo JL. Seventh Report of the Joint National Committee (JNC VII) on prevention, detection, evaluation, and treatment of high blood pressure. Hypertension, (2003), 42:1206-52.

7. Çakır H. Hipertansiyon Hastalarına Verilen Eğitimin Sağlıklı Yaşam Biçimi Davranışları ve Hipertansiyon Yönetimine Etkisi. Marmara Üniversitesi Sağl1k Bilimleri Enstitüsü İç Hastalıkları Hemşireliği Anabilim Dalı, Yüksek Lisans Tezi, İstanbul, (Danışman: Doç. Dr. Rukiye PINAR), (2003).

8. Çengel A. Yaşlilarda hipertansiyon ve hiperlipidemi tedavisi ve son gelişmeler. Türk Geriatri Dergisi, (2012), 15: 13-14.

9. Çubukçu S. Edirne'deki 65 Yaş ve Üzeri Bireylerde Hipertansiyon Prevalansı, Günlük Yaşam Aktiviteleri ve Yaşam Kalitesi Üzerine Etkisi. Erciyes Üniversitesi Sağlık Bilimleri Enstitüsü, Yüksek Lisans Tezi, Kayseri, (Danışman: Yard. Doç. Dr. Sultan Taşc1), (2005).

10. Dickinson HO., Mason JM., Nicolson DJ., Campbell F., Beyer FR., Cook SW., Williams B., Ford GA. Lifestyle interventions to reduce raised blood pressure: a systematic review of randomised controlled trials. J Hypertens, (2006), 24: $215-233$

11. Erciyes Y. Hipertansiyonlu Hastalarda Hemşire Tarafindan Verilen Eğitimin Sağlıklı Yaşam Biçimi Davranışlarına Etkisinin Değerlendirilmesi. Marmara Üniversitesi Sağlık Bilimleri Enstitüsü, Yüksek Lisans Tezi, İstanbul, (Danışman: Doç. Dr. Sezgi ÇINAR), (2013).

12. Erdine S., Ecder T., Ayla Ş., Solakoğlu D., Dülger H. Arteryel Hipertansiyon Tedavi Kılavuzu, Tedavi Stratejileri: Yaşam Tarzı Değişlikleri. Avrupa Hipertansiyon Derneği-Avrupa Kardiyoloji Derneği Çalışma Grubu, İtalya, (2007), s: 40-42.

13. Erkoç Balız S. Eskișehir Mahmudiye'de Erișkinlerde Hipertansiyon İnsidansı ve Risk Faktörleri. Eskişehir Osmangazi Üniversitesi Tıp Fakültesi, Halk Sağlığ1 Anabilim Dalı Tıpta Uzmanlık Tezi, Eskișehir, (Danıșman: Prof. Dr. Burhanettin IŞIKLI), (2013).

14. Göçgeldi E., Babayiğit MA., Hassoy H., Açıkel CH.,Taşçı İ., Ceylan S. Hipertansiyon tanısı almış hastaların algıladıkları yașam kalitesi düzeyinin ve etki eden faktörlerin değerlendirilmesi. Gülhane T1p Dergisi, (2008), 50:172-179.

15. Hansson L., Lindholm H., Ekbom T., Dahlöf B., Lanke J., Scherstén B., Wester PO., Hedner T., Faire U. Randomised trial of old and new antihypertensive drugs in elderly patients: cardiovascular mortality and morbidity the Swedish trial in old patients with hypertension-2 study. The Lancet, (1999), 354(20): 1751-1756.

16. Holt EW., Muntner P., Joyce CJ., Webber L., Krousel-Wood MA. Health-related quality of life and antihypertensive medication adherence among older adults. Age and Ageing, (2010), 1-7.

17. Kaya A., Gedik V., Bayram F., Bahçeci M., Sabuncu T., Tuzcu A., Arıkan Ș., Gökalp D. Hipertansiyon, Obezite ve Lipit Metabolizması Hekim İçin Tanı ve Tedavi Rehberi, Türkiye Endokrinoloji ve Metabolizma Derneği, Ankara, (2009), s:949.

18. Malhotra R., Angelique C., Malhotral C. Prevalence, awareness, treatment and control of hypertension in the 
elderly population of Singapore. Hypertension Research, (2010), 33: 1223-1231.

19. Mancia G., Fagard R., Narkiewicz K., Redon J., Zanchetti A., Böhm M., Christiaens T., Cifkova R., Backer D.E., Dominiczak A., Galderisi M., Grobbee DE., Jaarsma T., Kirchhof P., Kjeldsen SE., Laurent S., Manolis AJ., Nilsson PM., Ruilope LM., Schmieder RE., Sirnes PA., Sleight PA., Viigimaa M., Waeber B., Zannad F. 2013 ESH/ESC Guidelines for the management of arterial hypertension. The Task Force for the management of arterial hypertension of the European Society of Hypertension (ESH) and of the European Society of Cardiology (ESC). European Heart Journal, (2013), 34(28), 2159-2219.

20. Mergen H., Tavlı T., Öngel K., Mergen Erdoğmuş B., Tavlı V. Yaşlılarda hipertansiyona yaklaşım. Türkiye Aile Hekimliği Dergisi, (2010), 14(4): 167-172.

21. METSAR araştırıcıları. Türk erişkinlerde metabolik sendrom prevalans1. TKD XX. Ulusal kongresi, Antalya, (2007).

22. Miller CA. Seeing Older Adults Through the Eyes of Wellness. Lippincott Williams\&Wilkins, Philadephia, (2009).

23. Nguyen QT., Anderson SR., Sanders L., Nguyen LD. Managing hypertension in the elderly: A common chronic disease with increasing age. Clinical, (2012), 5(3):253-259.

24. Onat A., Yüksel M., Köroğlu B., Gümrükçüoğlu A., Aydın M., Çakmak HA., Karagöz A., Can G. TEKHARF 2012: Genel ve koroner mortalite ile metabolik sendrom prevalans1 eğilimleri. Türk Kardiyol Dern. Arş., (2013), 41(5): 373-378.

25. Önal E., Tümerdem Y. Yaşl1lıkta hipertansiyon. Türk Geriatri Dergisi, (2001), 4(4):141-145.

26. Paolaa P., Neil P. Hypertension management and control among English adults aged 65 years and older in 2000 and 2001. Journal of Hypertension, (2004), 22(6): 1093-1098.

27. Pekel Ö., Arık H., Sözmen MK., Ünal B., Kalaça S. Türkiye'de kan basıncı düzeylerindeki değişim. Turk Public Health, (2013), 11(3):129-148.

28. Polat Ü., Kahraman Bayrak B. Yaşlı bireylerin sağlıklı yaşam biçimi davranışları ve algılanan sosyal destek arasındaki ilişki. Fırat Tıp Dergisi, (2013), 18(4): 213-218.

29. Primatesta P., Poulter NR. Hypertension management and control among English adults aged 65 years and older in 2000 and 2001. Journal of Hypertension, (2004), 22: 1093-1098.

30. Safar H., Chahwakilian A., Boudali Y., Debray-Meignan S., Safar M., Blacher J. Arterial stiffness, isolated systolic hypertension, and cardiovascular risk in the elderly. Am J Geriatr Cardiol, (2006), 15: 178-82.
31. Sansoy İ. Türk Erişkinlerde Beden Kitle İndeksi, Bel Çevresi ve Bel Kalça Oranları. İçinde: Türk Erişkinlerde Kalp Sağlığg Risk Profili ve Kalp Sağlığı. Ed: Onat A., Ohan Matbaacılık Ltd. Şti., İstanbul, (2000), s: 46-55.

32. Soydan İ. Hipertansiyon ile ilgili TEKHARF çalışması verileri ve yorumu. Türk Erişkinlerde Kalp Sağlığ (TEKHARF). Argos iletişim, İstanbul (2003).

33. Staessen J., Gasowski J., Wang JG., Thijs L., Hond ED., Boissel JP., Coopee J., Ekbom T., Şarlı Ş. Hipertansiyon Hastalığ 1 Olanlarda Tedaviye Uyum, Etkileyen Faktörler ve Yaşam Kalitesinin Değerlendirilmesi. Erciyes Üniversitesi Tıp Fakültesi, Halk Sağlığı Anabilim Dalı Tıpta Uzmanlık Tezi, Kayseri, (Danışman: Doç. Dr. İskender GÜN), (2011).

34. Trevisol D., Moreira LB., Kerkhoff A., Fuchs SC., Fuchs F. Health-related quality of life and hypertension: a systematic review and meta-analysis of observational studies. Journal of Hypertension, (2011), 29(2): 179-188.

35. Türk Hipertansiyon ve Böbrek Hastalıkları Derneği (2012) www.turkhipertansiyon.org/ppt/PatenT2.ppt (Erişim tarihi: 3 Mart 2016).

36. Türkiye Endokrinoloji Metabolizma Derneği (2011) www. turkendokrin.org/files/file/TURDEP_II_2011.pdf (Erişim Tarihi: 8 Mart 2016).

37. Türkmen E., Badır A., Ergün A. Koroner arter hastalıkları risk faktörleri: primer ve sekonder korunmada hemşirenin rolü. Acıbadem Üniversitesi Sağlık Bilimleri Dergisi, (2012), 3(4): 223-231.

38. Walsh J., McDonald KM., Shojania KG., Sundaram V., Nayak S., Lewis R., Owens D., Goldstein MK. Quality improvement strategies for hypertension management: a systematic review. Medical Care, (2006), 44(7): 646-657.

39. Weber MA., Schiffrin EL., White WB., Mann S., Lindholm LH., Kenerson JG., Flack JM., Carter BL., Matersin BJ., Ram V., Cohen DL., Cadet JC., Charles R., Taler S., Kountz D., Townsend RR., Chalmers J., Ramirez AJ., Bakris GL., Wang JW., Schutte AE., Bisognano JD., Touyz RM., Sica D., Harrap SM. Clinical practice guidelines fort he management of hypertension in the community a statement by the American society of hypertension and the International Society of Hypertension. The Journal of Clinical Hypertension, (2014), 16(1): 14-26.

40. Wu MP., Wu SV., Wang TC., Kao MJ., Yang WL. Effectiveness of a community-based health promotion program targeting people with hypertension and high cholesterol. Nursing and Health Sciences, (2012), 14:173-181. 
